\title{
Recente visies op het leven na de dood in het Oude Testament
}

\author{
M.J. Paul
}

\begin{abstract}
Usually it is assumed that the Israelites had a negative view of the afterlife in the Old Testament, with some exceptions in the later texts. In several recent publications, in the last twenty years, changes are made. In this article these new visions are described and to some extent evaluated. Important questions are: What does the word sheol mean and is it the destination of believers? How can we interpret the many gifts for the deceased found in burial places in Israel? Related to the view on life after death, is the view of the nature of man. What is the meaning of nefesh (soul) and ruah (spirit)? And how do we have to view God's judgment: only in this life or also after death?

This article gives an overview of recent approaches, without going into detailed exegesis. The goal is to stimulate further research on this subject, that is also related to the study of the New Testament, Anthropology and Judaism.
\end{abstract}

In vergelijking met het Nieuwe Testament geeft het Oude een minder duidelijk zicht op het leven na de dood. ${ }^{1}$ In de afgelopen eeuw overheerste bij onderzoekers de overtuiging dat de Israëlieten een tamelijk negatieve opvatting hadden over de dood en over het leven daarna. In de laatste geschriften van het Oude Testament zou een verandering zichtbaar worden, die in de intertestamentaire periode nog groter is geworden. ${ }^{2}$ De laatste jaren treedt een wijziging op in de consensus en menen diverse onderzoekers dat er in het Oude Testament toch meer bekend is over het besef van een leven na de dood, en dat er meer continuiteit is met de latere opvattingen.

In dit artikel, dat zich richt op publicaties uit de afgelopen twintig jaar, komt eerst een Joodse onderzoeker aan het woord. Daarna bezien we het begrip sjeool. Vervolgens staan we stil bij archeologische gegevens over de rotsgraven in Juda in de koningentijd. Bij de vraag naar het leven na de dood is het ook belangrijk om na te gaan wat de nefesj ('ziel') van de mens is. Naar

1 Het artikel is een bewerking van lezingen over dit onderwerp, gehouden aan de Evangelische Theologische Faculteit in Leuven (4 sept. 2019) en voor het Oudtestamentisch Werkgezelschap in Amsterdam (6 febr. 2020).

2 Bijv. in Wijsheid 2-5 en 2 Makkabeeën 7. 
aanleiding van een gevonden grafstèle passeren diverse bijbelteksten de revue. Ten slotte komt het oordeel, in en na dit leven, aan de orde. In de afronding van het artikel staat de conclusie dat er genoeg redenen zijn om bepaalde gangbare opvattingen nieuw te doordenken.

\section{Levenson en het rabbijnse jodendom}

In 2006 publiceerde Jon Levenson Resurrection and the Restoration of Israel. Volgens hem is het een centraal leerstuk in het rabbijnse jodendom, dat aan het eind van de geschiedenis, God de doden zal opwekken en aan hen opnieuw een lichamelijk bestaan zal geven. Als voorbeeld noemt hij het Achttiengebed, waarin staat: ' $U$ bent machtig voor eeuwig, mijn Heer. U bent degene die de doden doet herleven, $U$ bent machtig om te redden. Hij onderhoudt de levenden in zijn gunst en doet de doden herleven uit grote barmhartigheid (...). Gezegend bent U, o Heer, die de doden doet herleven.'3

Levenson constateert dat de opstandingsgedachte vaak beschouwd wordt als een christelijke innovatie of als een afwijking van het vroegere jodendom. Deze misvatting ontvangt steun vanuit de consensus onder specialisten in de uitleg van de Hebreeuwse Bijbel. Levenson parafraseert die overeenstemming als volgt: de dood wordt beschouwd als een deel van Gods schepping en vormt dus geen theologisch schandaal. Alle mensen die stierven, werden verondersteld af te dalen naar de sombere onderwereld die bekendstaat als sjeool, en waaruit geen terugkeer mogelijk was. Slechts zeer laat in de periode van de tweede tempel, toen de laatste boeken in de Hebreeuwse Bijbel werden geschreven, kwam er een alternatieve opvatting.

Levenson noemt de veronderstelde aanleiding om destijds tot een andere visie te komen: 'De hoop op opstanding ontstond door de noodzaak om de martelaren te compenseren voor hun ondergang, om aan te tonen dat God rechtvaardig is. Een belangrijke bron van deze radicaal nieuwe verwachting lag in het Zoroastrisme, een Iraanse religieuze traditie, die een opstanding van de doden leerde.'4

De auteur is het geheel oneens met de genoemde visie en beargumenteert dit in zijn boek. Hij bespreekt het voortleven van mensen in hun familie en nageslacht, en tevens de grote verschillen in manieren van sterven. Zegen en vloek gelden volgens hem niet alleen in dit leven, maar ook in het leven na de dood. Daarom betwijfelt hij of Abraham, Mozes en Job in sjeool kwamen toen

3 Jon D. Levenson, Resurrection and the Restoration of Israel. The Ultimate Victory of the God of Life, New Haven 2006, 3. Vgl. Simcha Paull Raphael, Jewish Views of the Afterlife, derde editie Lanham 2019.

4 Levenson, Resurrection, ix-x. 
zij stierven. Tevens behandelt hij Gods wijze van omgaan met zijn volk Israël, waaruit blijkt dat er steeds weer redding komt. De ondertitel van het boek van Levenson is belangrijk: The Ultimate Victory of the God of Life.

De conclusie van het boek is dat Gods handelen zich ook uitstrekt over het leven na de dood. Het is waar dat de visie op opstanding zich in de loop van de tijd ontwikkeld heeft, zeker bij de profeten, maar volgens Levenson kan het latere jodendom zich ten aanzien van de opstanding terecht baseren op de Hebreeuwse Bijbel.

\section{Johnston en sjeool}

Uit de vele argumenten die Levenson hanteert, kiezen we voor de bespreking van het belangrijkste Hebreeuwse woord voor de onderwereld, namelijk sjeool. Hiervoor biedt een studie van Philip S. Johnston een goed uitgangspunt. ${ }^{5}$ (a) Het is het meestgebruikte woord voor de situatie van de mens na de dood, namelijk 66 keer. $^{6}$

(b) Het staat altijd zonder het bepaalde lidwoord ('de'), wat impliceert dat het een eigennaam is.

(c) Het verwijst naar het rijk van de doden, dat volgens diverse beschrijvingen zich diep in de aarde bevindt.

Het woord komt voor in de volgende genres:

- Psalmen, liederen en gebeden: 21

- Wijsheidsliteratuur: 20

- Profetische teksten: 17

- Verhalende teksten: 8

Het patroon van aanwezigheid van het woord leidt Johnston tot drie belangrijke waarnemingen. ${ }^{7}$ Ten eerste komt de term meestal voor in de liederen, in de wijsheidsliteratuur en in de profetische literatuur, waar de auteurs persoonlijk betrokken zijn bij hun werk. Daarentegen komt het woord sjeool slechts zelden voor in beschrijvende verhalen, en dan nog bijna alleen in de directe rede. Het komt nooit voor in de vele verhalende weergaven van een

5 Philip S. Johnston, Shades of Sheol: Death and Afterlife in the Old Testament, Downers Grove 2002. Johnston steunt op het ongepubliceerde werk van Ruth Rosenberg, The Concept of Biblical Sheol within the Context of Ancient Near Eastern Beliefs, Ph.D. Harvard University, 1981.

6 65x in de MT, plus een keer in Jes. 7:11 (emendatie; LXX). Vgl. THAT II:837-842. Het woord komt ook voor in Qumranteksten (8x in 1QH). De Septuaginta vertaalt meestal met hades.

7 Johnston, Shades, 70-85. 
overlijden, of het nu aartsvaders, koningen, profeten, priesters of gewone mensen betreft. De term duidt op persoonlijke, emotionele betrokkenheid, die te maken heeft met de verwachting van ondergang in verlatenheid door God.

Ten tweede wordt de term gebruikt in alle perioden van de geschiedenis van Israël. Ten derde is het opmerkelijk dat sjeool zo zelden voorkomt, gezien de lengte van het Oude Testament en de frequente verwijzingen naar de dood. De wortel 'sterven/dood' ( $m-w-t)$ komt duizend keer voor, ${ }^{8}$ maar er zijn slechts ongeveer honderd verwijzingen naar de onderwereld met behulp van sjeool of een synoniem. De conclusie is dat de onderwereld geen centraal begrip van het Oude Testament is, terwijl dat anders ligt bij de literatuur van de buurvolken.

\section{Vertaling}

In het bovenstaande is aangenomen dat sjeool de onderwereld aanduidt, het rijk van de doden diep onder de aarde. Dit wordt bijna algemeen geaccepteerd vanwege de combinatie met het werkwoord 'afdalen'. Omdat dit verblijf vaak geassocieerd wordt met de goddelozen, werd de term meermalen vertaald als 'hel', bijvoorbeeld in de King James Version en de Statenvertaling. ${ }^{9}$ De teksten wijzen echter niet op enige vorm van bestraffing na de dood, en daarom beschouwt Johnston deze vertaling als ongepast.

Omdat sjeool soms geassocieerd wordt met de rechtvaardigen, menen enige geleerden dat het woord geen onderwereld aanduidt, of althans niet altijd. Zij bestrijden dat de rechtvaardigen en goddelozen dezelfde bestemming in de onderwereld krijgen. Zo stelt Alexander Heidel (1949) dat het woord vaak 'het graf betekent, zoals blijkt uit de verwijzingen naar pracht, wormen, maden en zwaarden (Jes. 14:11; Ezech. 32:26-27). ${ }^{10}$ R. Laird Harris (1961) meent dat sjeool altijd het graf betekent, zoals blijkt uit parallelle verwijzingen naar de dood, het graf, de kuil, het stof enzovoort. In overeenstemming hiermee interpreteert hij verwijzingen naar het bestaan in sjeool als figuratief. ${ }^{11}$ Harris was lid van het vertaalteam van de New International Version en beïnvloedde de vertaling op dit punt, zodat daar vaak de weergave 'grave' staat. ${ }^{12}$ Deze opvatting kan echter niet consequent worden doorgevoerd, zoals de

\section{THAT I:894b.}

9 Johnston vermeldt dat de KJV 31x 'hell' vertaalt, 31x 'grave' en 3x 'put' (Shades, 73, n. 17).

10 Alexander Heidel, 'Death and the Afterlife' in The Gilgamesh Epic and Old Testament Parallels, Chicago 1949², 137-223.

11 R. Laird Harris, 'The Meaning of the Word Sheol as Shown by Parallels in Poetic Texts', BETS 4 (1961), 129-135. Zie ook zijn bijdrage in TWOT, 892-893.

12 Johnston, Shades, 74. 
NIV ruimschoots illustreert. Harris negeert in Jesaja 14:9 de personen die in het dodenrijk worden opgeroepen om de gevallen tiran te groeten. In Amos 9:2 is de tegenstelling 'diepten van het graf en 'klimmen naar de hemel' niet erg waarschijnlijk.

In Nederland heeft de Herziene Statenvertaling, gepubliceerd in 2010, vaak de vertaling 'graf. In Amos 9:2 staat echter 'hel' en in Jesaja 14 is gekozen voor 'het rijk van de dood'.

Het woord sjeool komt bijna uitsluitend voor in het bijbels Hebreeuws. Er is in de bijbelse periode maar één voorbeeld van het gebruik elders, in een Aramese tekst uit de $5^{\text {de }}$ eeuw voor Christus, van de Joodse gemeenschap in Elephantine in Egypte. ${ }^{13}$ Omdat de onderwereld een wijdverbreid concept was in het oude Nabije Oosten, is het opmerkelijk dat het Hebreeuws een unieke aanduiding heeft. Hierdoor konden de Israëlieten de term voorzien van hun eigen godsdienstige inhoud, zonder de conceptuele bagage die internationaal gedeelde termen dragen. Het taalkundig onderscheiden karakter maakte een duidelijker uitdrukking van theologische eigenheid mogelijk.

\section{Bestemming}

Wanneer de teksten worden geclassificeerd op inhoud, blijkt dat de term meestal de menselijke bestemming aangeeft, vooral het lot van de goddelozen. Toch verwachten enige rechtvaardige personen een afdaling naar sjeool. Dit geldt Jakob, Hizkia, Job en de psalmist Heman (Ps. 88). Ze spreken echter allen in het kader van een extreme situatie van verlies, ziekte, ellende of verlating. Hizkia, Job en de psalmist interpreteren hun omstandigheden als goddelijk oordeel. Verder is het selectieve gebruik van sjeool in de geschiedenis van Jakob opmerkelijk. Hij vreest twee keer een droeve afdaling naar deze plaats, bij het aannemen van Jozefs dood en bij vrees voor het lot van Benjamin (Gen. 37:35; 42:38). Jaren later, nadat zijn gezin herenigd is, wordt Jakobs dood herhaaldelijk en op verschillende manieren vermeld, maar dan wordt sjeool niet meer genoemd. ${ }^{14}$ Het valt dus te beargumenteren dat de rechtvaardigen alleen sjeool voor zich zien als ze geconfronteerd worden met een ongelukkige en vroegtijdige dood, die ze interpreteren als een goddelijke straf. Wanneer ze sterven na een voltooid en gezegend leven, is er geen sprake van deze bestemming. Deze redenering van Johnston berust op diverse observaties, maar er blijft een marge van onzekerheid.

13 Johnston, Shades, 77.

14 Rosenberg, The Concept of Biblical Sheol, 87-88. 
In afwijking van het bovenstaande wordt sjeool twee keer gepresenteerd als de bestemming voor iedereen: in Psalm 89:48-49 en Prediker 9:7-10. ${ }^{15}$ Deze teksten verdienen nader onderzoek. Psalm 89:48-49 merkt op dat het leven kort is en de mensen vergeefs geschapen lijken. De dichter vraagt retorisch of iemand de dood en sjeool kan ontwijken. Deze vraag vindt plaats in de context van een goddelijk oordeel. De term 'tevergeefs' verwijst ook naar veroordeling. Vanuit die optiek lijkt iedereen bestemd voor sjeool.

De tweede tekst, Prediker 9:7-10, geeft de lezers het advies om te genieten van hun leven van 'damp' (hèbèl) onder de zon, omdat ze later naar sjeool gaan waar geen werk, gedachte, kennis of wijsheid is. In het boek is er ook het thema van vertrouwen in God, die alle daden zal beoordelen (3:17; 11:9; 12:14). Dit impliceert een vorm van definitieve rechtspraak. Johnston meent dat de uitspraak over allen die naar sjeool gaan, deel is van de reflectie op het geobserveerde, absurde leven, maar het is niet het laatste woord. ${ }^{16}$

Het lijkt mij dat de nadruk op het oordeel terecht is. Het woord hèbèl is echter niet altijd negatief en de betekenis ervan varieert in het boek Prediker. Het is onwaarschijnlijk dat het boek het dagelijkse leven als 'absurd' beschouwt. ${ }^{17} \mathrm{De}$ wijsheidsleraar observeert 'onder de zon', en beschrijft wat er in deze wereld te zien is. Daar is de ervaring dat mensen naar hun negatieve bestemming gaan, beschreven als een plek zonder alle mogelijkheden van dit leven. Dit is niet hetzelfde als een algemene uitdrukking van het lot van alle mensen.

Kortom: sjeool kan niet simpel worden opgevat als de Hebreeuwse term voor de onderwereld die iedereen wacht. Volgens Johnston is het woord bijna uitsluitend gereserveerd voor degenen die onder goddelijk oordeel verkeren, hetzij de goddelozen, hetzij de getroffen rechtvaardigen, of alle zondaars. Het woord komt zelden bij de hele mensheid voor, en alleen in contexten die de menselijke zondigheid uitbeelden. Deze opvatting van Johnston is overgenomen door diverse andere onderzoekers, zoals Levenson en Raharimanantsoa. ${ }^{18}$

15 In Ps. 139:8 worden twee uitersten beschreven. Spr. 27:20 en 30:16 spreken over onverzadigbaarheid, maar geven niet aan dat dit lot alle mensen treft.

16 Johnston, Shades, 83.

17 Craig G. Bartholomew, Ecclesiastes (BCOTWP), Grand Rapids 2009, 84-96, en Mart-Jan Paul, 'The Translation of Hebel in Ecclesiastes', in S. Riecker en J. Steinberg (red.), Das heilige Herz der Tora. FS Hendrik Koorevaar, Aken 2011, 285-301.

18 Levenson, Resurrection, 72-74 en Mamy Raharimanantsoa, Mort et Espérance selon la Bible Hébraïque, Stockholm 2006, 96-99. Paul R. Williamson, Death and the Afterlife. Biblical perspectives on ultimate questions, 2017, 132, gaat niet mee met deze interpretatie, omdat volgens hem de genoemde teksten Ps. 89:48 en Pred. 9:10 het lot van alle mensen beschrijven. 


\section{Suriano over rotsgraven}

Steeds vaker worden archeologische vondsten betrokken bij de uitleg van de opvattingen van Israël over het leven na de dood. ${ }^{19}$ Matthew J. Suriano schreef A History of Death in the Hebrew Bible. ${ }^{20}$ In dit boek wil hij laten zien dat het concept van de dood meer gericht was op de behandeling van de doden dan op hun lot. De dood, in de wereld van de schrijvers van het Oude Testament, was volgens hem een dynamisch proces - dat we dying noemen - in plaats van een statische gebeurtenis. Hij is het niet eens met Roland Murphy die het bestaan na de dood in de bijbelse literatuur beschreef als 'non-life' en voor het graf en sjeool het woord 'afterdeath' gebruikte in plaats van 'afterlife'. ${ }^{21}$

Het eerste deel van zijn boek heet: The Archaeology of Death in Iron Age Judah. Daarin legt de auteur de nadruk op de archeologische vondsten. Een Judese graftombe in de koningentijd had meestal drie banken, uitgehakt in de zijwanden tegenover de ingang. Het graf had ook een aparte plaats voor de tweede begrafenis van de doden, namelijk de verzamelplaats voor de beenderen. Dit is vaak een put, uitgehouwen onder een bank, of een specifieke plaats op de vloer.

Bij de eerste begrafenis werd het dode lichaam gelegd op een van de banken in het graf. In deze situatie werd de dode voorzien van voedsel, drank en andere benodigdheden, zoals een lamp. Zodra het lichaam werd verwijderd van de bank, voor de tweede begrafenis (ook wel ossilegium genoemd), verloren de grafgiften hun functie. De vondst van lampen zonder roetsporen toont aan dat ze nooit werden gebruikt en dat hun functie symbolisch was. ${ }^{22} \mathrm{Het}$ graf diende als een huis voor meerdere generaties van doden en het was een permanent symbool van de verbondenheid met de voorouders.

De zorg voor de doden en het verschaffen van voedsel wijzen erop dat het lichaam in de overgangsfase op de ligbank nog in een proces van sterven verkeerde. Volgens Suriano was de gewoonte van het begraven van de doden in een graf met ligbanken uniek voor Juda tijdens de IJzertijd, al zijn er verbindingen met eerdere en latere praktijken. ${ }^{23}$

In Lachis zijn diverse Judese graven ontdekt en opgegraven. Een massa-

19 Zie Angelika Berlejung, Bernd Janowski (red.), Tod und Jenseits im alten Israel und in seiner Umwelt. Theologische, religionsgeschichtliche, archäologische und ikonografische Aspekte, Tübingen 2009.

20 Matthew J. Suriano, A History of Death in the Hebrew Bible, Oxford 2018.

21 Suriano, History, 4-5.

22 Dat geldt ook voor de overige grafgoederen. Suriano, History, 48-51.

23 Suriano, History, 56. 
graf dat daar aangetroffen werd, is zeer waarschijnlijk het resultaat van het Assyrische bloedbad tijdens Sanheribs campagne in de tijd van Hizkia (in 701 v.Chr.). Veel botten zijn verbrand en de schedels zijn gescheiden van de skeletten begraven. In dit massagraf zijn varkensbeenderen gelegd in een bewuste poging de overblijfselen van de doden van Judeeërs te ontwijden. ${ }^{24}$

Een ander Judees graf is gevonden in Ketef Hinnom in Jeruzalem. ${ }^{25}$ In graf 24 zijn twee zilveren amuletten met Hebreeuwse inscripties ontdekt. Deze inscripties vertonen overeenkomst met de priesterlijke zegen in Numeri 6:2327. Het tweede amulet heeft als (gereconstrueerde) tekst: 'Moge hij/zij gezegend worden door JHWH, de strijder en degene die het kwaad verdrijft. Moge JHWH u zegenen, u bewaken. Moge JHWH zijn aangezicht over u laten lichten en $u$ vrede geven. ${ }^{.26}$ Dit is een aanwijzing dat het geloof in de God van Israël samenging met het geven van grafgiften.

Suriano behandelt in het tweede deel van zijn boek Death and the Afterlife in the Hebrew Bible. Hij combineert hier de gegevens vanuit de archeologie en de bijbelteksten. De auteur is van mening dat de grafgiften ook kunnen duiden op een maaltijd waarbij de levenden met de doden aten. ${ }^{27}$ In ieder geval was het bestaan van de gestorvenen afhankelijk van de zorg die de levenden gaven. Die zorg betreft het verschaffen van voedsel en het zich herinneren van de namen. De Hebreeuwse Bijbel ontkent deze praktijken niet, maar beperkt ze wel. Dit blijkt uit Deuteronomium 26:14, waar een Israëliet moet verklaren wat hij met zijn tienden heeft gedaan. Een deel van deze verklaring luidt: 'Ik heb er niet van gegeten terwijl ik in rouw was, er niets van weggenomen toen ik onrein was en er niet van meegegeven aan een dode.'28

In de Hebreeuwse Bijbel is overleving na de dood verbonden met het lichaam. Het voortbestaan na de dood is niet afhankelijk van mummificatie, zoals in Egypte, maar van een zorgvuldige verzameling van de beenderen. Het verhaal van Izebels beenderen ( 2 Kon. 9:36-37) is er een van vernietiging, niet van een hiernamaals. ${ }^{29}$

24 Suriano, History, 80-82.

25 Gabriel Barkay, 'Excavations at Ketef Hinnom in Jerusalem', in Hillel Geva (red.), Ancient Jerusalem Revealed, Jerusalem 1994, 85-106. Zie ook Barkay, 'The Riches of Ketef Hinnom', BAR 35-4/5 (2009), 22-35, 122, 124, 126.

26 Suriano, History, 124.

27 Suriano, History, 157.

28 Suriano, History, 162, verwijst ook naar Hosea 9:4, waar sprake is van 'brood voor rouwenden'. Hij meent dat de daar genoemde zielen niet verwijzen naar de rouwenden, maar naar de overledenen.

29 Suriano, History, 197-198. 
Sjeool is onmiskenbaar somber. In tegenstelling daarmee is het familiegraf een ideaal dat nooit negatief beschreven wordt. Suriano suggereert dat sjeool een tijdelijke staat voor de dode is. Deze tijdelijke status komt overeen met het tijdelijke verblijf van het dode lichaam op een ligbank in een Judees graf. Net zoals iedereen het proces van sterven ondergaat, gaan allen naar sjeool. In de tombe wordt dit proces via rituele praktijken begeleid, tot in de collectieve ruimte van de beenderen. Van belang zijn de vereniging met de voorouders, een goede begrafenis en het hebben van nageslacht. ${ }^{30}$

\section{Evaluatie}

Suriano zoekt nieuwe wegen om het sterven in het Oude Testament te interpreteren. Het blijkt dat hij wel vasthoudt aan de opvatting dat sjeool voor allen is, terwijl we eerder zagen dat Johnston en anderen die gedachte loslieten. Een nieuw punt is de tijdelijkheid van sjeool, maar het is de vraag of teksten over de verlossing uit de greep van die verblijfplaats (bijv. Ps. 16 en 116) zo uitgelegd kunnen worden.

Het is interessant om de grafgiften te analyseren en te verbinden met de uitleg van de bijbelteksten. Ondanks de vele vondsten blijft de interpretatie moeilijk. Het is vaak onmogelijk in herhaaldelijk gebruikte grotten vast te stellen of eten en drinken alleen aanvankelijk werden verstrekt, voor de reis van de overledene naar de onderwereld, of continu, voor voortdurend levensonderhoud. De aanvulling van eten en drinken kon in ieder geval niet plaatsvinden in eenvoudige graven, maar alleen in rotsgraven die herhaaldelijk gebruikt worden. Het is ook vaak onmogelijk de etnische afkomst van de doden te bepalen en zo vast te stellen of het verstrekken van voedsel en drank door Israëlieten of door niet-Israëlieten werd beoefend. ${ }^{31}$ Zelfs in het geval dat Israëlieten of Judeeërs voedsel verstrekten en amuletten met bijbelse teksten gaven, is het niet duidelijk of dit wel of niet toegestaan was in de godsdienst van Israël, of dat dit voorbeelden zijn van syncretisme. Het blijkt bijna onmogelijk de archeologische vondsten goed te interpreteren.

\section{Steiner en de ziel}

Nauw verwant met de mogelijkheid van voortbestaan na de dood is de opvatting over de nefesj ('ziel'). Blijft deze bestaan na de dood van het lichaam? In de afgelopen eeuw benadrukten veel geleerden dat er geen afzonderlijk voort-

30 Suriano, History, 247-248.

31 Vgl. Johnston, Shades, 64. 
bestaan was. ${ }^{32}$ Hierin onderscheidt het Hebreeuwse zich van het Griekse denken. Richard C. Steiner laat in zijn recente boek Disembodied Souls een ander geluid horen. ${ }^{33}$ Hij wil terugkeren naar de vroegere visie en probeert aan te tonen dat in enige teksten een niet-lichamelijke ziel bedoeld is. Hij stemt ermee in dat vaak een algemenere vertaling mogelijk is, zoals 'adem', 'persoon' of 'zelf. Daarom is het noodzakelijk om passages te vinden in de Hebreeuwse Bijbel, waar nefesj niet alleen 'ziel' kan betekenen, maar waar dit woord ongetwijfeld deze betekenis heeft. Hij meent dat Ezechiël 13:17-21 hieraan voldoet, een passage over vrouwen die iets naaien om zielen te vangen. Het is een uiterst moeilijk gedeelte, maar Steiner gebruikt zeer veel materiaal om zijn interpretatie te illustreren. $\mathrm{Na}$ de behandeling van deze 'bewijstekst' volgt de bespreking van andere gedeelten.

Aan het einde van de $19^{\text {de }}$ eeuw hebben enige geleerden gesuggereerd dat Ezechiël 13 verwijst naar een magische manier van het vangen van zielen. James G. Frazer schreef in zijn werk The Golden Bough: A Study in Comparative Religion (1890) over die praktijk. 'Zielen kunnen gescheiden worden van hun lichamen of op hun omzwervingen worden vastgehouden, niet alleen door geesten en demonen, maar ook door mensen, vooral door tovenaars. Wanneer in Fiji een crimineel weigerde te bekennen, liet de hoofdman een sjaal halen om de ziel van de schurk te vangen.' Na pagina's met dergelijke voorbeelden merkte Frazer in een voetnoot op: 'Enige tijd geleden suggereerde mijn vriend professor W. Robertson Smith mij dat de beoefening van de jacht op zielen, die in Ezechiël 13:17vv aan de kaak wordt gesteld, vergelijkbaar moet zijn.' 34

In 1897 nam Alfred Bertholet in zijn commentaar op Ezechiël het als vanzelfsprekend aan dat de gevangen zielen van levende mensen waren, ${ }^{35}$ terwijl drie jaar later Richard Kraetzschmar meende dat in ieder geval sommige van hen geesten van de doden in de onderwereld waren, die uit hun rust werden gehaald door dodenbezwering. ${ }^{36}$ Steiner is het ermee eens dat Ezechiël verwijst naar onstoffelijke zielen, die zich, althans tijdelijk, buiten het menselijke lichaam bevinden.

32 Joel B. Green schrijft in het artikel 'Soul', NIDB 5:339: 'Biblical studies ... since the early 20th century almost unanimously supports a unitary account of the human person.' Zie ook Hans Walter Wolff, Anthropology of the Old Testament, Londen 1974, 10-25.

33 Richard C. Steiner, Disembodied Souls. The Nefesh in Israel and Kindred Spirits in the Ancient Near East, with an Appendix on the Katumuwa Inscription, Atlanta 2015.

34 Frazer, The Golden Bough, 1890, 117 en 120. Geciteerd in Steiner, Disembodied Souls, 6.

35 Alfred Bertholet, Das Buch Hesekiel, Freiburg i. B. 1897, 72 (Seelenfängerei).

36 Richard Kraetzschmar, Das Buch Ezechiel, Göttingen 1900, 35 (Mantik und Nekromantik). 


\section{Katumuwa}

Voordat de auteur nader ingaat op de tekst uit Ezechiël, verwijst hij naar een belangrijke Aramese tekst die in 2008 ontdekt werd, in Zincirli (het vroegere Samal) in Zuidoost-Turkije. De vertaling van deze tekst luidt: 'Ik ben Katumuwa, ${ }^{37}$ dienaar van Panamuwa, die voor mezelf een stèle heeft verworven terwijl ik nog leefde en die in mijn eeuwige ontvangstruimte zette. Het feestelijke offer in deze ontvangstruimte is een stier voor Hadad (...), een ram voor de Beweger van de bergen, een ram voor Sjamasj, een ram voor Hadad van de wijngaarden, een ram voor Kubaba en een ram voor mijn ziel, die in deze stèle is. En (van?) nu, wie ook uit mijn zonen (...), laat hem elk jaar, uit de opbrengst van deze (aangrenzende) wijngaard, een schaap kopen en laat hem het naast mijn ziel slachten en mij een dijbeen presenteren. 38

Katumuwa was een dienaar van koning Panamuwa II die stierf circa 733/732 voor Christus. In de inscriptie komt de Aramese term nebesj (in het Hebreeuws nefesj) twee keer voor. Volgens de vijfde regel zal de nefesj van Katamuwa in de stèle zijn. Die steen lijkt een pied-à-terre te zijn voor bezoeken vanuit de onderwereld.

Was dit een algemeen aanvaarde mening? Volgens David Schloen en Amir Fink is dat niet het geval. Zij menen dat hier een contrast is met de traditionele West-Semitische opvatting dat iemands ziel in het lichaam blijft na de dood, maar dat de mening in overeenstemming is met Hittitische/Luwische (en meer in het algemeen Indo-Europese) opvattingen over het hiernamaals, waar de ziel door middel van crematie uit het lichaam wordt vrijgelaten. ${ }^{39}$

Aanwijzingen voor crematie ontbreken echter, en er zijn veel overeenkomsten met de dodencultus in Mesopotamië, zoals voedselgiften aan de zielen van de doden, het gebruik van standbeelden als verblijfplaatsen voor zielen die voor een feest genodigd zijn, en de aanroeping van de namen van de zielen. ${ }^{40}$ Bewijs voor onstoffelijke zielen is ook beschikbaar in Ugaritische teksten. In de Egyptische cultus zijn verschillende spirituele delen van de mummies bekend, zoals $b a$, akh en $k a$. Kortom: het geloof aan het bestaan en

37 Tegenwoordig is de schrijfwijze Katumuwa, terwijl in eerste instantie gedacht werd aan Kuttamuwa $($ Katu $=$ strijd). Christopher B. Hays bespreekt deze stèle ook in zijn boek $A$ Covenant with Death. Death in the Iron Age II and Its Rhetorical Uses in Proto-Isaiah, Grand Rapids 2015. De voorkant van het boek bevat een afbeelding van deze stèle.

38 Zie de vertaling in Steiner, Disembodied Souls, Appendix 1, 128-162.

39 J. David Schloen en Amir S. Fink, 'New Excavations at Zincirli Höyük in Turkey (Ancient Sam'al) and the Discovery of an Inscribed Mortuary Stele', BASOR 356 (2009), 1-13 (11).

40 Steiner, Disembodied Souls, 18-19. 
aan het voortleven na de dood van onstoffelijke zielen was wijdverbreid in het oude Nabije Oosten.

Het is waar dat de overtuiging dat mensen een ziel hebben die de dood overleeft, niet hetzelfde is als een geloof in onstoffelijke zielen. Niettemin lijkt het duidelijk dat de twee overtuigingen vaak samengaan.

\section{Het vangen van zielen}

$\mathrm{Na}$ deze uiteenzetting bespreekt Steiner in detail Ezechiël 13:17-21. Vroeger werd het woord kesatot vertaald met 'kussens', maar latere vertalingen hebben meestal 'toverbanden'. Toch is op basis van het Misjna-Hebreeuws de eerste vertaling beter. Er zullen kussenslopen bedoeld zijn, zonder enige vulling. De vrouwen naaiden stukjes stof of leer om slopen te maken met het doel de zielen van hun slachtoffers te vangen of te bewaren. Het woord mispahot duidt op lapjes stof die gebruikt werden als vulling voor de kussenslopen. Waren dit stukjes stof van de kleding van het beoogde slachtoffer? De zielen werden gevangen in (niet met!) de kussens. ${ }^{41}$ Deze vertaling vergroot de aantrekkelijkheid van Frazers reeds genoemde interpretatie. Hij noemde ook 1 Samuël 25:29 'De nefesj van mijn heer zal worden gebonden in de bundel van de levenden in de zorg van JHWH, uw God; maar Hij zal de nefesj van uw vijanden (als) in de holte van een slinger wegslingeren.' Beide teksten spreken over zielen in zakken.

In veel culturen wordt verondersteld dat de zielen van slapende mensen het lichaam verlaten. Hekserij werkt op twee manieren, namelijk, om iets uit een mens te halen, of om iets in hem te brengen. In deze situatie worden vallen gebruikt om de zielen te vangen. De magie in Ezechiël 13 weerspiegelt een angst die wijdverbreid was onder de Egyptenaren: dat het dagelijkse verkeer van de $b a$-ziel zou worden verstoord, dat die ziel verhinderd zou worden om weer in het lichaam te komen.

\section{Onderscheiden van het lichaam}

Wanneer deze opvatting over nefesj klopt, kunnen we ons afvragen of er meer teksten zijn waarin de nefesj van het lichaam wordt onderscheiden. Steiner noemt drie teksten. ${ }^{42}$ In Genesis 35:18 wordt het sterven van Rachel omschreven als 'En het was tijdens het uitgaan van haar nefesj'. Elia maakt in 1 Koningen 17:22 mee dat de nefesj van het dode kind terugkeerde in zijn bin-

41 Steiner, Disembodied Souls, 43. Voor een andere benadering, zie John F. Evans, 'DeathDealing Witchcraft in the Bible? Notes on the Condemnation of the 'Daughters' in Ezekiel 13:17-23', Tyndale Bulletin 65.1 (2014), 57-84.

42 Steiner, Disembodied Souls, 68-80. 
nenste, zodat het herleefde. In Hooglied 5:6 is de bruid buiten zichzelf. 'Mijn nefesj ging uit toen hij sprak.'

In de eerste twee teksten vertrekt de nefesj bij de dood en keert hij terug bij het herleven. De ruimere interpretatie 'leven' is problematisch, omdat bij het kind de uitdrukking 'in zijn binnenste' staat. Aanvullend bewijs dat nefesj geen 'leven' in het algemeen betekent, staat in Psalm 116:7 'Keer terug, mijn nefesj, tot je rustplaats'. Zielen werden in de Oudheid gezien als een soort poppen die door kunstenaars konden worden afgebeeld. ${ }^{43}$ Een dichter kon zich richten tot zijn nefesj en deze aanspreken. Het Egyptische Middenrijk weerspiegelt de visie van de $b a$-ziel als een aparte manier van bestaan - in dit geval een alter ego met wie de eigenaar een dialoog kan voeren.

\section{Geest}

$\mathrm{Nu}$ keren we ons tot de ruah ('geest'), omdat die meermalen in hetzelfde verband genoemd wordt. De precieze relatie tussen de begrippen nefesj en ruah is niet eenvoudig te bepalen. Steiner vermoedt dat de nefesj opgevat werd als bestaande uit twee componenten: (1) De nefesj habbāśär, een lichamelijk bestanddeel in het bloed, en (2) de ruah, een geestelijke component die door God geschonken is. Leviticus 17:11 stelt 'De nefesj habbāśär is in het bloed ... want het is het bloed dat, door middel van de nefesj (daarin), verzoening bewerkt.'

Het is interessant dat Philo van Alexandrië lang geleden iets dergelijks voorstelde: 'We gebruiken "ziel" op twee manieren, zowel voor de hele ziel als ook voor het belangrijkste deel, dat "de ziel in de ziel" is. ... En daarom oordeelde de wetgever dat de ziel tweeledig is, het bloed dat van de ziel als geheel is, en de goddelijke adem of geest dat zijn belangrijkste deel is. ${ }^{44}$

\section{Verschuiving van inzichten}

De traditionele visie op de ruah is verwoord door Charles A. Briggs (1900) en opgenomen in het woordenboek van Brown-Driver-Briggs. Deze auteur schrijft dat de term ruah vaak voorkomt ( 25 keer) met de betekenis 'geest van het levende, ademhalende wezen, verblijvend in het lichaam van mensen en dieren'. ${ }^{45}$ Volgens Briggs duidt ruah de geest aan die in de mens leeft en die bij de dood vertrekt. Een van zijn bewijsteksten is Prediker 12:7 'en het stof [= het vlees] keert terug naar de grond, zoals het (eerder) was, en de ruah keert

43 Steiner, Disembodied Souls, 79.

44 Philo, Who is the Heir of Divine Things, par. 55. Steiner, Disembodied Souls, 83-84.

45 Charles A. Briggs, 'The Use of רוח in the Old Testament', JBL 19 (1900), 132-145 (137). 
terug naar God, die hem geschonken heeft.' Dit wijst op een dualistisch concept van de mens.

Achteraf blijkt dat het artikel van Briggs het einde van een tijdperk markeerde. Minder dan tien jaar na de publicatie werden twee uitdagingen voor de traditionele kijk op de bijbelse ruah gepubliceerd, de ene chronologisch en de andere semantisch van aard. De chronologische uitdaging erkende dat een dualistische opvatting van het menselijk wezen gevonden kon worden in de Hebreeuwse Bijbel, maar alleen in zijn jongste boeken. ${ }^{46}$ Er zijn volgens Steiner echter goede redenen om aan te nemen dat het idee van een nietlichamelijke ziel in de meeste lagen van de Bijbel te vinden is. Denk aan het onderscheid in Psalm 104:29; 146:4; Job 34:14-15 en Prediker 12:7 (vgl. 3:2021) tussen de aardse bestemming van het lichaam en de hemelse bestemming van de geest. Dit onderscheid is geen latere import van een Iraanse of Griekse opvatting, maar is ook aanwezig in de Egyptische dodenboeken.

De tweede uitdaging was een nieuwe semantische aanpak. Als gevolg van de verschuiving werd ruah in de bovenstaande voorbeelden opgevat in de betekenis van 'adem' in plaats van 'geest'. 47

Steiner geeft toe dat het moeilijk is om een beslissende weerlegging van dit standpunt te bieden, maar het is wel mogelijk te laten zien dat de betekenis 'adem' soms minder passend is dan de betekenis 'geest'. De interpretatie 'adem' heeft niet veel zin in verzen die spreken over de terugkeer van de ruah tot God. Het bestaan van een niet-lichamelijke ruah werpt licht op aanvullende argumenten voor het bestaan van een onstoffelijke ziel. Die argumenten worden vaak genegeerd in de discussies omdat hierin de termen nefesj en ruah niet voorkomen. ${ }^{48}$ Het gaat over de uitdrukking 'Hij werd verzameld tot zijn verwanten' en soortgelijke bewoordingen. De fysieke interpretatie is niet altijd mogelijk, omdat niet iedereen op dezelfde plaats begraven werd. Dit brengen gebeurt na de dood, maar nog voor de begrafenis. Deze twee fasen worden genoemd bij koning Josia (2 Kon. 22:20) en Izak (Gen. 35:29).

Alexander Heidel schrijft: 'Er kan geen twijfel over bestaan dat de genoemde spreekwijzen verwijzen naar het onsterfelijke element in de mens. Een duidelijke indicatie daarvan staat in Psalm 49:19-20: Al prijst hij zich in zijn leven gelukkig, al looft men $\mathrm{u}$, omdat $\mathrm{u}$ zichzelf te goed doet, toch zal hij komen tot het geslacht van zijn vaderen; voor altijd zullen ze het licht niet zien.' ${ }^{49}$

46 Isaac Broydé en Ludwig Blau, 'Soul', in Jewish Encyclopedia, New York 1907, 11:472b.

47 William Ross Shoemaker, 'The Use of רוח in the Old Testament', JBL 23 (1904), 13-67.

48 Steiner, Disembodied Souls, 93.

49 Heidel, Gilgamesh, 188. 
Een andere uitdrukking in de Pentateuch is dat de nefesj wordt afgesneden van zijn verwanten. In de $13^{\text {de }}$ eeuw schreef Nachmanides in zijn commentaar op Leviticus 18:29 dat de nefesj de dood overleeft. Teksten als Numeri 15:30 en Leviticus 22:3 leren volgens hem dat de nefesj die zondigt zal worden afgesneden, maar dat de andere zielen, die niet gezondigd hebben, voor God in heerlijkheid zullen bestaan. Jacob Milgrom stemt hiermee in: het is mogelijk dat het afsnijden betrekking heeft op de straf na de dood. Dan wordt het de zondaar niet toegestaan zich in het hiernamaals bij zijn voorouders te voegen. Hij suggereert dat de uitdrukkingen 'inbrengen' en 'afgesneden worden' antoniemen zijn..$^{50}$

Deze overwegingen brengen Steiner tot zijn conclusie dat de nefesj ook zonder het lichaam kan bestaan. Hij bepleit terugkeer tot de eerdere visie op dit onderwerp dan in de afgelopen eeuw overheersend was.

\section{Het oordeel}

Als we aannemen dat de nefesj na de dood voortleeft, waar gaat deze naartoe? Is er verschil in bestemming? Veel geleerden beschouwen een goddelijk gericht over de doden als een vrij late ontwikkeling in de godsdienst van Israël. Het goddelijk oordeel vindt meestal plaats in dit leven, en niet na afloop ervan of na de geschiedenis. In Daniël 7, meestal gezien als een late tekst, leidt de Oude van dagen een hemels gerechtshof waar boeken worden geopend. Veel teksten voorzeggen meer in het algemeen een definitief oordeel dat verbonden is met 'de dag van JHWH'. De profeten laten er geen twijfel over bestaan dat JHWH zowel de naties als zijn eigen volk zal oordelen en dat Hij dat volgens hun werken zal doen. De nadruk ligt echter op Gods historische oordelen, zoals de zondvloed in de tijd van Noach of de vernietiging van Sodom en Gomorra.

Vele malen wordt 'het oordeel overeenkomstig de werken' genoemd in het Oude Testament. Deze uitdrukking heeft niet altijd dezelfde retorische functie. ${ }^{51}$ In Psalm 62 luidt de laatste zin: 'U vergeldt ieder naar zijn werk.' KyoungShik Kim schreef een monografie over dit onderwerp. ${ }^{52}$ Hij betoogt dat de meerderheid van de latere passages over dit thema in feite interpretaties

50 Jacob Milgrom, Leviticus 1-16 (AB), New York 1991, 459-460, in een discussie over mogelijke verklaringen.

51 Vgl. Williamson, Death and Afterlife, 96-101.

52 Kyoung-Shik Kim, God Will Judge Each One According to Works: Judgment According to Works and Psalm 62 in Early Judaism and in the New Testament, Berlijn 2011. 
van Psalm 62 zijn. Deze auteur vraagt aandacht voor Gods kracht en Gods goedheid (hesed) in dit lied. Het slotvers verklaart beide eigenschappen en is dus van toepassing zowel op de bestraffing van de goddelozen als op de vrijspraak van de rechtvaardigen. ${ }^{53}$ Dit oordeel vindt plaats na de dood.

Bij dit onderwerp zijn ook de wijsheidsboeken Spreuken en Prediker van belang. In Spreuken gaat het meestal over de effecten van goed en verkeerd gedrag in dit leven. Dit is echter niet altijd het geval. Een paar teksten lijken te wijzen op een realiteit na de dood. 'Als er een ramp komt, worden de goddelozen neergehaald, maar zelfs in de dood hebben de rechtvaardigen een toevluchtsoord' (Spr. 14:32). De NIV StudyBible stelt in een voetnoot over de rechtvaardigen: 'Hun geloof in God geeft aan hen hoop voorbij het graf.' Spreuken 15:11 stelt: 'Sjeool en vernietiging liggen open voor JHWH' en 12:28 zegt: 'In de weg van de gerechtigheid is er leven; de weg in het spoor [voert] niet naar de dood.' Wat is de betekenis van 'leven' voor de rechtvaardigen? Het is niet het natuurlijke leven, maar het overvloedige leven in relatie tot God, een leven dat niet wordt beëindigd door de dood of het graf. De goddelozen leven op deze aarde, maar ze worden nooit beschreven als levend in de sfeer van licht en leven. Ze zijn in de sfeer van duisternis en dood. Ze zijn al dood, reeds in dit leven, omdat ze geen relatie hebben met de levende God (2:22; 1:26-32). Spreuken $23: 17$ stelt dat de hoop van de vromen op de toekomst niet zal worden teleurgesteld; in tegenstelling daarmee hebben de goddelozen geen hoop voor de toekomst. Het boek Spreuken wijst op iets onsterfelijks van de mens, maar er zijn geen uitspraken over een lichamelijke opstanding.

De hoop op een hiernamaals is in overeenstemming met het Egyptische geloof in een leven na de dood. De Egyptische scholen waar wijsheid werd onderwezen, werden 'Scholen van het leven' genoemd. Aangezien Spreuken afhankelijkheid van Egyptische wijsheid toont, zou het verrassend zijn als 'het leven' met de levende God minder dan de Egyptische hoop van het leven met hun goden betekende. Ook de uitdrukking 'boom des levens' in 3:18 kan wijzen op een leven dat meer is dan alleen de periode van het graf. ${ }^{54}$

In Prediker wordt meerdere malen gezegd dat de dood voor alle mensen is. Allen hebben een gemeenschappelijk lot (bijvoorbeeld 9:1-3). Qohelet verwerpt

53 Kim, God Will Judge, 43-54. Vgl. Williamson, Death and Afterlife, 100-101.

54 Bruce K. Waltke, The Book of Proverbs, Chapters 1-15 (NICOT), Grand Rapids 2004, 104106. 
echter niet de goddelijke vergelding, maar hij concludeert op basis van zijn observaties dat Gods oordeel niet altijd in dit leven wordt gezien (3:16-17; 8:1014). De manier van leven heeft gevolgen, maar niet altijd op korte termijn.

Het is belangrijk om te geloven dat God goed zal zijn voor de mensen die Hem ontzag betonen. Maar omdat de goddelozen dit niet doen, zal het niet goed met hen gaan (8:12-13). Wijsheid is beter dan dwaasheid, hoewel hetzelfde lot hun beiden overkomt (2:12-14). Qohelet komt met duidelijke adviezen voor dit leven, vooral ten aanzien van de eerbied voor God $(3: 14 ; 5: 6$; $7: 18 ; 8: 12)$.

Eenmaal komt het oordeel van God over de daden van de mens (3:17; 11:9; 12:14). Daarbij wordt opengelaten wanneer dit het geval is. Prediker 12:7 (zie ook 3:21) maakt duidelijk dat de geest van de mensen naar God gaat. Dit impliceert dat de dood niet het einde is. Ieder mens moet voor God staan. 'Want God zal elke daad in het gericht brengen, met alles wat verborgen is, hetzij goed, hetzij kwaad' (12:14). Dit is het antwoord op de vele teleurstellende waarnemingen.

Het bovenstaande houdt in dat er diverse bijbelboeken zijn die wijzen op een gericht na de dood. De datering van de genoemde boeken kan hier niet behandeld worden, maar er zijn goede redenen om aan te nemen dat de wijsheidsboeken uit de koningentijd stammen.

\section{Conclusie}

In de laatste eeuw van de oudtestamentische wetenschap overheerste de opvatting dat de Israëlieten zeer sombere opvattingen over de dood hadden. De sjeool met zijn vele negatieve aspecten was voor alle mensen. Gerelateerd aan deze opvatting is de holistische kijk op de persoonlijkheid van mensen. In de afgelopen jaren zijn er veel vragen gerezen en zijn er nieuwe interpretaties voorgesteld. Op basis van de aangevoerde argumenten lijkt het waarschijnlijk dat de Israëlieten een meer dualistische opvatting hadden dan lange tijd gedacht is. John W. Cooper vat deze visie samen als 'dualistisch holisme'. ${ }^{5}$ Deze benadering maakt het mogelijk aan te nemen dat de ziel of de geest de dood overleeft. Vooral de stèle van Katumuwa heeft bijgedragen aan een nieuwe (en in feite veel oudere) interpretatie van de nefesj. Ook archeologische vondsten van graven helpen ons om het uitzicht van de Israëlieten op het hiernamaals te heroverwegen. De mogelijkheid van een goddelijk oordeel na

55 John W. Cooper, 'The Current Body-Soul Debate: A Case for Dualistic Holism', SBJT 13.2 (2009), 32-50. 
de dood heeft belangrijke gevolgen voor de uitleg van diverse teksten. ${ }^{56}$ Ook zijn er consequenties ten aanzien van de bijbelse antropologie..$^{57}$

Met deze nieuwe richtingen in de studie van het hiernamaals worden niet alle problemen van de interpretatie opgelost. Het Oude Testament legt veel nadruk op het leven met God in het beloofde land, en minder op het leven na de dood. Sommige uitdrukkingen blijven erg moeilijk uit te leggen en er blijft nog veel werk te doen. ${ }^{58}$ Met de bovenstaande benaderingen komt de exegese van de oudtestamentische teksten in ieder geval dichter bij de rabbijnse interpretatie en bij de visie op het leven na de dood in het Nieuwe Testament.

M.J. Paul is deeltijdhoogleraar Oude Testament aan de Evangelische Theologische Faculteit te Leuven.

56 Vgl. M.J. Paul, e.a., (red.), Bijbelcommentaar Ezra - Job (SBOT 6), Veenendaal 2009, Excurs 8, 'Het leven na de dood in het Oude Testament', 859-877, en Bijbelcommentaar Psalmen I (SBOT 7), Veenendaal 2010, Excurs 4, 'Bijbels zicht op de mens', 878-891, of de geactualiseerde digitale versies (www.studiebijbel.nl).

57 Bernd Janowski heeft in zijn recente standaardwerk de opvattingen van Steiner nog niet verwerkt. Hij gebruikt Gen. 2:7 'de mens werd tot een levende nefesj' als locus classicus om de eenheid van de mens te benadrukken. Hij vertaalt in de stèle van Katumuwa met 'Person'. Zie Antropologie des Alten Testaments. Grundfragen - Kontexte - Themenfelder, Tübingen 2019, 48, 639. Richard Pleijel kiest echter voor de positie van Steiner in 'To Be or to Have a nephesh? Gen 2:7 and the Irresistible Tide of Monism', ZAW 131 (2019), 194206.

58 Vgl. de bespreking van het werk van Johnston en Levenson in Robin L. Routledge, 'Death and Afterlife in the Old Testament', JEBS 9-1 (2008), 22-39. 